\title{
CONFESSING THE ONE FAITH: \\ THEOLOGICAL RESONANCE BETWEEN \\ THE CREED OF NICEA (325 AD) AND \\ THE CONFESSION OF BELHAR (1982 AD) ${ }^{1}$
}

\author{
Piet Naude \\ Department of Theology \\ University of Port Elizabeth
}

\begin{abstract}
This paper explores the theological consonance between Nicea, the oldest ecumenical creed, and Belhar, the youngest Reformed confession, in the context of the World Council of Churches' project to find a common expression of the apostolic faith today.
\end{abstract}

\section{Introducing the Project: 'Toward the Common Expression of the One Faith Today'}

The important issue of some agreement on the "essentials" of the Christian faith, has been part of the modern ecumenical movement from its beginning. The first World Conference on Faith and Order (F\&O) in Lausanne (1927) included "The church's common confession of faith" in its agenda and was able to confirm: "We are united in the Christian Faith which is contained in the Holy Scriptures and is witnessed to and safeguarded in the Ecumenical Creed, commonly called the Nicene and in the Apostles' Creed, which Faith has been continuously confirmed in the spiritual experience of the followers of the Lord Jesus Christ.", With the formation of the World Council of Churches in 1948 in Amsterdam, "the visible unity of the church in one faith and in one eucharistic fellowship" emerged as the ultimate aim of the new organisation (WCC Constitution III, I, my emphasis).

The question of what this "one faith" exactly is, and how to reach unity in "one eucharistic fellowship" were two themes continuously addressed in subsequent years. The latter was taken up in the well-known BEM-project, ${ }^{3}$ whilst the first developed broadly as follows: The fourth F\&O World Conference in Montreal (1963) took up the very important question of how Scripture relates to Tradition (capital T) and traditions (small $t$ ) as well as the place of the creeds in such a hermeneutical framework. An intense study of the early church and its councils followed, investigating the possibilities of a genuinely Universal Council in modern times. But by 1967, the F\&O Commission Meeting judged that such efforts and studies toward a common confession was premature, and in 1971 (Louvain) shifted the focus rather to a contextual pluralism of credal witnesses and of accounts of hope. ${ }^{4}$ This culminated in the Bangalore (1978) statement "A common statement of our

1. Paper read at the Fifth Ecumenical Forum held under auspices of the Ecumenical Institute at the University of Heidelberg on 11 January 2003. I herewith give recognition and thanks to the director, Prof Christoph

Schwöbel, for the invitation, and to Dr Fernando Enns, Study Leader at the Institute, for our discussion of the theme.

2. Resolution 2 of the report on section IV, first draft, as published in the proceedings (see Bate 1928: 230-231).

3. See Baptism, Eucharist and Ministry 1982-1990, F\&O Paper 149, Geneva: WCC, 1990.

4. See the section "Giving account of the hope that is in us" (Louvain, F\&O Paper 59:215-216) where it is stated: "What we have in mind is not to take the form of a Creed, a Catechism, a statement of Confession or a kind of 
faith" (FO Paper 92, 1978, 244-246) where a number of important affirmations about the Trinitarian faith ${ }^{5}$ were made, including the search for a common confession of the shared apostolic faith. ${ }^{6}$

The search for such common confession was outlined in a three-stage study initiated at the Lima Commission meeting in 1982 under the title "Towards the common expression of the apostolic faith today". The three interdependent goals were: (1) A recognition of the Nicene Creed (without the filioque) as the ecumenical creed of the church. (2) An explanation of the creed for the sake of contemporary understanding, and (3) finding ways to an expression of the common faith today. The sixth assembly of the WCC in Vancouver (1983) affirmed the study project which included contemporary expressions of faith, as well as a focus on the Nicene creed as most striking model of unity in the early church, representing part of a consensio antiquitatis et universitatis (Sieben 1979:515). The possibility of Nicea as expression of the common apostolic faith, was pursued at a number of theological consultations (see Limouris 1991a:108-110) which led to the publication of a draft document Confessing the one faith (F\&O paper 140,1987) approved by the Standing Commission of F\&O in Madrid (1987). After considerable reactions and further deliberations around the world, the new revised version was approved in Dunblane, Scotland (1990) and published by the WCC as Faith and Order Paper 153 in 1991 under the title: Confessing the one faith. An ecumenical explication of the Apostolic faith as it is confessed in the Nicene-Constantinopolitan Creed (381).

My interpretation of the common confession-project is that it has retained a bi-focal vision of both recognition and explanation of the Nicene Creed and promoting "...new confessions of faith as they are provoked today by situations of persecution, of church union negotiations, or of urgent socio-economic, political or ideological threats". Such modern confessions "....could enrich the variety of credal expressions and ought to be communicated within the ecumenical community as concrete evidence that we are 'listening to what the Spirit has to say to the churches" (Houtepen 1991:197). Instead of considering such new expressions of faith as purely contextualist reactions to specific circumstances, ${ }^{7}$ it should be part and parcel of our theological task to show the coherence between "universally received" symbols (like Nicea or the Apostolicum) and such modern expressions, in order to confirm our one apostolic faith.

At this point it should be noted that the primary expression of the apostolic faith ${ }^{8}$ as "the dynamic reality of the Christian faith" remains the Holy Scriptures. Different

theological handbook. We should endeavour to express what is the content and meaning of our life and prayer and proclamation." This later led to the publication of the four part series Confessing our faith around the world published between 1980 and 1985 (Faith and Order Papers 104, 120, 123, and 126).

5. As example of the many Trinitarian passages: "We confess God's involvement in the history of humankind, revealed through Israel, fulfilled in Jesus Christ, communicated to us by the Holy Spirit, into which fulfilment all humanity is called" (246).

6. See specifically the preamble on pages $244-245$.

7. In his overview of confessions as communicative acts, Edmund Arens (1989) moves from Lehrendes Bekennen in the Councils and Bekenntnisschriften in the Reformation to what he calls Situatives Bekennen to depict twentieth century documents like Barmen (and by implication Belhar). The latter creates the unfortunate impression that the early creeds and confessions were "universal" (in the sense of a-contextual) and not in fact also situation-bound.

8. See George Vandervelde's discussion of at least six dimensions to the meaning of "apostolic faith" in the context of the WCC. He indicates that one such dimension relates to the Nicene Creed "...as the ecumenical symbol i.e. confessional document par excellance" (1998, 25, point 5). 
traditions however arose in the process of confession in post-biblical times with concomitant different views on the nature and authority of such confessions. Today the ecumenical church encompasses these views and their numerous internal variations from the distinct authority of select Ecumenical Councils, historically definitive confessions (Lutheran), and openness to new confessions in new circumstances (Reformed), to noncredal (Methodist) and even anti-credal churches (Pentecost, charismatic).

For this paper I take the Reformed view of confessions as point of departure. This is, firstly, the tradition from which I engage in ecumenical theology, and it is, secondly, the context from which the Belhar confession grew. From a Reformed perspective, three remarks are necessary as background to this discussion:

1. Scripture retains its position of ultimate criterion, the norma normans of faith, so that all subsequent expressions of faith are under Scripture and not next to it.

2. The symbols of the early church - notably the Nicene creed, the Apostolicum and the credo of Athanasius - are accepted with the confessions arising from the Protestant Reformation, ${ }^{10}$ as in agreement with Scripture (quia), and therefore as authoritative expressions of the apostolic faith.

3. In the light of its understanding of the church's witnessing role to the Word in new circumstances and against new heresies (semper reformanda), Reformed churches are open to continual and renewed confessions of faith, albeit subject to certain broad constraints. $^{11}$

An exploration of the apostolic faith as found in a new confession like Belhar in relation to earlier expressions of faith like Nicea, finds its inspiration therefore both in the specifics of the Confessing the one faith-project and in the Reformed habit of testing later expressions of faith in the light of earlier ones (representing an accumulated faith tradition), and ultimately in the light of Scripture. In the spirit of the Confessing-project, ${ }^{12}$ this paper will take the Nicean text as point of departure and do a comparative reading with the Belhar-

9. See the introduction to Confessing the one faith (page 2, par 7) that tries to avoid the idea that apostolic faith refers "to a single fixed formula" or "to a specific moment in Christian history".

10. In the Reformed churches of Dutch origin, the Three Formulae of Unity, i.e. the Belgic Confession, Heidelberg Catechism, and Canons of Dordt, occupy a pre-eminent position.

11. Karl Barth has been very influential in shaping the notion of confession. Already in 1925 he spoke to the World Alliance of Reformed Churches on the desirability and possibility of a general Reformed confession (the formulation of which he denied at the time). At that occasion he defined as follows: "A reformed creed is the statement, spontaneously and publicly formulated by the Christian community within a geographically limited area, which, until further action, defines its character to outsiders; and which, until further action, gives guidance for its own doctrine and life; it is a formulation of the insight currently given to the whole Christian Church by the revelation of God in Jesus Christ, witnessed to by the Holy Scriptures" (English version published as Theology and church. Shorter writings 1920-1928, see pp 132-133). Barth's other definition in the KD I/2: 693ff, in context of his discussion of the doctrine of God's Word, reads: "Eine kirchliche Konfession ist eine auf Grund gemeinsamer Beratung und Entschliessung zustande gekommene Formulierung und Proklamation der der Kirche in bestimmtem Umkreise gegebenen Einsicht in die von der Schrift bezeugte Offenbarung." And a third discussion is found in KD III/4:79-94 where Barth, drawing on his earlier work, puts forward four criteria for a confession: 1. It has no ulterior motive, because "es wird allein zu Ehre Gottes geschehen dürfen" (84). 2. It reacts to a moment when the faith is acutely questioned from inside or outside. "Der status confessionis ist also kein Dauerzustand" (86). 3. Confession is a communal act of the church and not a private matter. "Ein echter Bekenner wird sich niemals als Solist und auch nicht als Kammermusiker gebärden und verhalten" (90). 4. Confession is a free act as it responds to God's free grace. Therefore nobody can be coerced into confession. "Wer mit seinem Bekenntnis ins Offene geht... betritt eine Bergspitze, über der nur noch der Himmel ist" (93).

12. For a critical view of the Confessing-project from the realities of South African church divisions (and perhaps missing the ecumenical spirit?), see Naude 2002 
text, showing both similarities and differences, but with the overriding question in mind: Does Belhar confirm the apostolic faith as expressed in Nicea? ${ }^{13}$

The intention is twofold: This is a contribution to the first phase of explicating Nicea as Confessing the one faith undertakes in sub-section II of each article. But it is also a contribution to communicate to the ecumenical church ${ }^{14}$ the faith of Belhar, and in turn test this faith in the light of the most ecumenically accepted of all symbols.

Before we venture into a close reading of the respective texts, a few interesting, but hermeneutically significant remarks about Nicea and Belhar are made ${ }^{15}$ keeping in mind the fact that the audience of this paper will be fairly well informed about Nicea, but perhaps less so with regard to Belhar.

\section{Nicea and Belhar: Creating a Hermeneutical Basis for a Text Comparison}

\subsection{What is in a Name?}

Both Nicea and Belhar derive their names from the places where they were formulated. And in both cases there is indeed a lot in the name. In the case of Nicea, the full name Nicene-Constantinopolitan Creed (NC) ${ }^{16}$ points to the complexity of its formation over an extended period of time from the first ecumenical council held in the city of Nicea (20 May -19 June/25 July? 325) and its fuller and altered version as accepted by the second council in Constantinople (May - July 381). We will return to this complexity below, but wish at this stage to direct attention to the fact that both Councils were called by the Roman emperor ${ }^{17}$ (Constantin in the case of Nicea and Eusebius with Constantinople) ${ }^{18}$ and bore great political significance in ensuring religious unity for the sake of imperial unity. ${ }^{19}$ In the

13. There could obviously be a variation of answers to this question: Belhar could confirm the basic theological convictions of Nicea, or deny some of these. Or Belhar supercedes Nicea to confirm aspects of our common faith not testified to in Nicea. Or these "new elements" - if any - are not recognised as belonging to our common faith, but is collectively a mere contextual witness in a crisis situation. And so one can continue with various scenarios. The focus of this paper is quite narrow and specific and will mainly address the issue of consonance between Nicea and Belhar with the former taken as point of departure. I take theological resonance (as in the title of this paper) to mean at least a significant theological convergence, and not merely textual agreements or differences.

14. Anton Houtepen's reference (1991:197) to an ecumenical "Book of Confessions" as "an enriching possibility for dialogue and exchange of spiritual experiences" could therefore include Belhar as example of confessions from around the world (see footnote 4 above).

15. I am no Patristic scholar and have for Nicea's history and context relied on the following very informative secondary sources: Limouris 1991b (short orientation), Hauschild 1994 (on the text), Ritter 1978 (on Arianism), Perrone 1993 and Ritter 1999 (general history and theology) and the well-known classics by Sieben 1979 (on the Councils) and Kelly 1972 (on the early creeds). The best South African source is, as far as I know, WD Jonker's Christology, Christus die Middelaar, published in 1977, specifically pages 12-61. For Belhar fewer formal academic sources are available, although the list is growing. At this stage the most useful introductory source remains A moment of truth, edited by Cloete and Smit, and published in 1984 after the draft confession of Belhar was accepted in 1982. A layman's introduction in Afrikaans has been attempted by Botha and Naude 1998.

16. In this paper I will follow the custom of referring to the 381-document as NC, or as the Nicene Creed, whereas Nicea will refer to the earlier version of 325.

17. The first emperor's council already occurred in Arles in 314 to solve the problem of bishop Cecilan's election as bishop of Karthago (see Perrone 1993:26). As it was a meeting of bishops in the West only, it does not have the status of an ecumenical council.

18. After he defeated Licinius in 324 , Constantin ruled over the whole empire until his death in 337 . Theodosius I ruled in the West from 379, but after the murder of Gratian, he also ruled over the whole empire until 395.

19. In Nicea the emperor hosted the Council in his palace, paid for part of the cost, chaired the meeting, and closed the Council with a grand banquet which served as 20th commemoration of his rule. In Constantinopel, 
view of the Romans, the ruler carried responsibility for religious matters. "This view of the ruler as pontifex maximus was retained in Christianity and determined its view of the kingdom for centuries to come" (Perrone 1993:27, my translation). In this light it would therefore be seen as the duty of the emperor to participate in and influence ecclesial matters on the assumption of a unity between church and state only questioned and abolished in modern times.

The two names reflected in the Nicene Creed thus points to its close alignment with the political power of the day and the strategic ${ }^{20}$ importance of the councils per se as representing the common view of the churches in both the West and the East.

The confession of Belhar takes its name from a fairly humble so-called "coloured" suburb near Cape Town. Under apartheid rule, political power was represented by "Cape Town", the seat of legislative power where over the period 1948 and onward South African society was segregated in every respect on racial grounds. Belhar, as physical space, was in itself a result of the infamous Group Areas Act that dispossessed "non-whites" of land and grouped them in segregated black, coloured and Indian residential areas and townships (informal settlements). Belhar as ecclesial space also represented separation, because the Dutch Reformed Mission Church who gathered in its general synod at Belhar in 1982 (22 Sept - 6 Oct) ${ }^{21}$ was formed in 1881 as the result of the establishment of separate churches ${ }^{22}$ for different race groups within the Dutch Reformed Church (that was itself established in Cape Town via Dutch settlement in 1652).

In contrast to Nicea that spoke from and for the "centre" in a situation of political and ecclesial unity, Belhar spoke from the margins, and represented both political and ecclesial schism. But this does not imply that Belhar at the time represented weakness or political insignificance. The reason for this is twofold:

First: Although South Africa, after the formation of the Union in 1910, de jure accepted a separation of church and state, the close-knit relation between party, church, culture and volk in Afrikaner nationalism constituted a de facto corpus christianum after the National Party came to power in 1948. In fact, the very idea of apartheid as political system had part of its roots in a specific brand of neo-Calvinist (Abraham Kuyper) and missiological thinking (Gustav Warneck), and some of the apartheid laws were enacted at the request of the DRC (e.g. prohibition of mixed race marriages). The whole system

the Council was called by the emperor, but met in a church and was chaired by bishops, first Melitius (who died at the Council) followed by Gregorius of Nazians and later Nectarius of Constantinopel. In both cases the decisions of the Councils were enacted by imperial law as well as canon law. See Perrone 1993:33,56, 71-72. See Max Stackhouse's suggests that we see in this relation between ecclesia and imperium "...the fundamental issue of what could hold diverse, conflict-ridden, protocosmopolitan societies together" by asserting the truth of "metaphysical-moral ideas" underlying any effort to build a society - even up to today. He commends the fathers for resisting the efforts to sanctify the status of the emperor (Stackhouse 1989:185).

20. It seems as if Constantin had the city of Ancyra in Galatia in mind for the first council. He changed the venue to Nicea as gesture of compromise to the Aryans who might have felt wary of the outspoken anit-Aryanism of the bishop of Ancyra. See Perrone 1993:33.

21. The draft confession was accepted on the last day of the synod, Wednesday 6 October 1982. For a moving account of events at the synod, see Johan Botha's narrative in Botha and Naude 1998:33-37.

22. The other two churches are the Dutch Reformed Church in Africa (DRCA, black church) and the Reformed Church in Africa (RCA, Indian church) who together with the DRC (white church) and DRMC form the DRC-family of Reformed churches. The white Reformed community is divided into three further churches: The Gereformeerde Kerk, Hervormde Kerk (both from the late nineteenth century and reacting to events in The Netherlands) and the Afrikaanse Protestantse Kerk (APK) which split off from the DRC when the latter church started to move away from a theological support for apartheid after 1986. 
of white of SA, solidified with the formation of the Republic in 1961 under Hendrik Verwoerd, constituted a close-knit unity that lived off religion for its moral legitimacy. $^{23}$

Thus: the common and unquestioned assumption of both defenders and opponents of apartheid was that the church really matters. ${ }^{24}$ The socio-political system of apartheid was interpreted theologically, and the theological (ecclesiological) struggle was not about interesting theoretical ideas, but about liberation or continued oppression. In this sense, the voice of Belhar was of great political significance. Although spoken from Belhar, the words fell right in Cape Town where the rulers knew that the legitimacy of their system was at stake.

Second: The voice of Belhar was influential and powerful, because it was not a voice calling from the wilderness, but from the very heart of the ecumenical church. The involvement of the broader church in the SA struggle needs not be repeated here. In a recent paper $^{25}$ on Belhar's antecedent witnesses, I showed how Catholic, Lutheran, Black, Reformed and ecumenical declarations from 1948 to 1982 came together in the draft confession (1982) as ultimate form of Christian witness against irreconcilability and for the unity in Christ.

\subsection{What is in a Heresy?}

From the earliest church, creeds and confessions normally had the double aim of being a summary of the true faith for baptismal or catechetical purposes, and a contra-statement against some form of heterodoxy. In both Nicea and Belhar the content has been deeply influenced by that which they were set up against. Although Nicea is a creed and Belhar a Bekenntnisschrift, and they therefore belong to slightly different ecclesial and liturgical genres, both texts are characterised by the structure of "true faith" and "heresy". ${ }^{26}$

In Belhar this is quite evident from the fact that the three middle articles all end with a "Therefore, we reject..."- clause wherein the specific dimension of the false doctrine is clearly exposed in the light of the preceding positive statement of the gospel: Article 2 rejects any doctrine that would endanger the visible unity of the church; article 3 rejects any doctrine which sanctions forced racial separation in the name of the gospel and therefore deny the reconciliation in Christ; article 4 rejects any ideology which legitimizes societal injustice and a doctrine which would be unwilling to resist such injustices. From these rejections the middle structure of Belhar, i.e. unity, reconciliation and justice naturally flows, "encircled" by the articulation of faith in the triune God (article 1) and call to obedience (article 5).

23. For a very good overview of apartheid as a theology, see the well-known books by De Gruchy 1979 (English) and Kinghorn 1986 (Afrikaans), and my recent attempt to summarise the roots of apartheid theology, Naude 2002a (submitted for possible publication in 2003 in Missionalia, an international missiological journal based in South Africa).

24. For a discussion and original sources, see Naude 2001.

25. The paper, written for a seminar on Barmen and Belhar at the University of Heidelberg (Germany) in the winter-semester of 2002, is entitled: The theological coherence between the Belhar confession and some antecedent church witnesses in the period 1948 -1982. (Naude 2002b). It has been submitted for possible publication in 2003 by Verbum et Ecclesia, a South African theological journal.

26. Karl Barth (1948:704) clarifies this point by emphasising that if you cannot see the No! of a confession, the credo of the Yes! remains silent. 
In Nicea the situation is, for historical reasons, more complex. The original text of Nicea 325 is much shorter than the version of NC 381 known to us today. ${ }^{27}$ What is interesting to note, is that the shorter version included as part of the main text a clear rejection clause (anathema) ${ }^{28}$ whereas the final version has no explicit rejection clauses, but is built on implicit rejections ${ }^{29}$ taken up into the main text. It is generally accepted in scholarship that Nicea 325 was primarily directed against the Arian ${ }^{30}$ heresy in the context of the early church's search for an adequate expression of Trinitarian theology, and that NC 381 was an extension of the earlier text to address new heresies that arose in the mean time and required an extension of the earlier version with special emphasis on the eighth article about the Holy Spirit (see Limouris 1991b:727, Perrone 1993:27-31; Hauschild 1994: 449-454). Read from the anathema "backwards", one would therefore expect Nicea 325 and NC 381 to deal with the issue of the Trinity, with specific references to the relation of the Son, i.e. the Logos, to the Father, and (in the light of the "pneumatomachians"31 later) the question of the divinity of the Spirit, and how the one God could be confessed as a trinity without compromising the unity of God (on the one hand) and the divinity of each of the three persons in the Trinity (on the other).

In what way the Trinitarian confession of NC and Belhar's five articles relate to one another, will hopefully be apparent from the textual analysis below.

\subsection{What lies in Reception?}

The process of reception of both $\mathrm{NC}$ and Belhar is of historical and theological significance.

In the case of $\mathrm{NC}$, the process of reception ${ }^{32}$ was in fact constitutive for the final formulation itself. In the period between 325 and 381 the faith of Nicea was carried forth in both the East and the West and in the end found to be an inadequate expression of the faith

27. Nicea has 141 words which includes the anathema of 42 words, and has no amen, whereas NC consists of 174 words plus the Amen. For a detailed analysis of the two versions and comparisons, see Hauschild's article in the TRE (1994:444 - 456).

28. The rejection clause refers explicitly to two quotations drawn from Arian theology and is concerned with the second person of the Trinity: hn pote lote ouk Vhn (there was a time that he was not) and prin gennhqena ouk hn (before he was borne he was not). The clause ends with: toutous anaqhmatizei lh kaqolikh kai apostolokh Ilekklhsia (this the catholic and apostolic church rejects).

29. For a list of these implicit rejections (without discussion) related to the text of NC 381, see Limouris $1991 \mathrm{~b}: 727$.

30. Arius (260-337?) from Alexandria built his ideas on Hellenistic metaphysics in relation to specifically the Logos-concept (found in the Johannine gospel). To retain the absolute unity and transcendence of God, only God can be the agennhtos arzh, so that the Son as Logos must be ktisma or poinma (creation, something made). The consequence is that the Son cannot be accepted as equally eternal with the Father (like in Origenes): as a created being there was a time when the Son was not. The motive to protect the unity, indivisibility and transcendence of God led to a subordination of the Son. See Adolf Ritter TRE 3, 1978: 693-719 for a fuller technical discussion.

31. In the first half of the 4th century the focus of the Arian discussion was on the relation between the Father and the Son. Therefore Nicea 325 has an extended confession on Jesus Christ, mostly retained in 381, but with a very short confession about the Spirit: And (we believe) in the Holy Spirit (kai /eis ton agion pnuema). In NC 381 it is this article that is expanded significantly to address the heresy that the Spirit is not equally divine in relation to the other two Persons in the Trinity. This heresy (named after the pneumatomachians, meaning "spirit-fighters") is mentioned the first time in 360 by Athanasius and apparently arose in Egypt with support from Macedonius of Constantinople (therefore sometimes called the Macedonian heresy). See Perrone 1993: 66-68.

32. For a discussion of the technical meaning of reception in the ecumenical movement and a comprehensive bibliography up to 1998, see Naude and Smit 2000. 
in the sense that it did not address all the important heresies pertaining to the Trinity. What is even more remarkable is the fact that no documentary evidence from the 381-Council itself suggests that $\mathrm{NC}$ was formulated and accepted in Constantinople. We have confirmation of this only via the reception of NC at the next Councils of Ephesus in 431 and specifically of Chalcedon in 451 which refers back to the 150 fathers' acceptance of the NC-creed in 381 (Perrone 1993: 81). ${ }^{33}$ One further textual change occurred after 381 with the insertion of the filioque ${ }^{34}$ by the West between the 7th and 9th century (which contributed to the eventual split between the East and West). But the creed is attested to in liturgies as early as 488 and is accepted in both the East and West as expression of true faith. The churches of the Reformation - both Lutheran and Reformed - accepted NC as basis for faith, although its liturgical use has been superseded by the Apostolicum. The WCC process of Confessing the one faith, therefore rightly builds on the most ecumenical of all Christian symbols.

The confession of Belhar was accepted as draft confession at the Synod of the Dutch Reformed Mission Church (DRMC) on 6 October 1982. It was subsequently distributed to all congregations of the DRMC for comment and formally accepted as fourth Bekenntnisschrift at the synod of 1986. Its reception has since then gone through a variety of phases: Firstly it was accepted internally by the members of the DRMC ${ }^{35}$ as expression of their faith in a situation of oppression that constituted a status confessionis. Secondly it was accepted as basis of faith in the unification of the DRMC and the Dutch Reformed Church in Africa (DRCA) into the Uniting Reformed Church of Southern Africa (URCSA) on 14 April 1994. ${ }^{36}$ Thirdly Belhar was accepted or noted by a number of churches outside ${ }^{37}$ South Africa like the Verenigde Protestantse Kerk in Belgium, ${ }^{38}$ the Evangelisch Reformierten Kirche in Bayern und Nordwestdeutschland and the Reformierten Bund in Germany as well as by the Reformed Ecumenical Council (from which the URCSA has withdrawn). Fourthly, Belhar has been and will form part of the re-unification process of the DRC-family ${ }^{39}$ which will resume with new energy in 2003 with the hope of full re-unification by 2007.

33. It is interesting to note that, according to Perrone, the Council of Ephesus' decision on 22 July 431 to declare $\mathrm{NC}$ as adequate and only expression of the faith, must not be interpreted as if new symbols of faith could not later be accepted. "Nicea was accepted as highest norm and criterion of faith without excluding the further development of creeds" (Perrone 1993:81, my translation).

34. The recently published Habilitationsschrift on the filioque by Bernd Oberdorfer (2000), now professor at Augsburg, is a comprehensive treatment of the struggle about the procession of the Spirit from both the Father and the Son. I find the view of Max Stackhouse $(1989: 182,196)$ from a non-credal perspective illuminating, as he suggests that the omission of the filioque actually opens the opportunity to see the work in the Spirit in both Judaism and other religions where Christ is not acknowledged as Lord and Son of God.

35. At the 1986-synod 10 of the 267 congregations voiced their concerns with Belhar, and 24 of the 498 delegates did not sign the confession at first. See Smit 1998: 26.

36. Some congregations of the DRCA did not join the re-unification and remains legally as separate church until this day.

37. In discussing the legacy of Abraham Kuyper, one of the leaders of the URCSA, Russel Botman (2000:346), attempts to show convergence between Belhar and some liberative trends in Kuyper's thought. He then notes with frustration: "Why this first Reformed confession conceived on African soil received so little, if any, attention from Reformed churches internationally, and particularly among Kuyperians and Barthian scholars, remains a mystery."

38. This church included Belhar in its church orders in 1998. For an overview and informative discussion, see De belijdenis van Belhar published by the Verenigde Protestantse Kerk in Belgium (2001). The German churches mentioned above included Belhar in the official partnership documents between themselves and the URCSA.

39. For a discussion of the DRC's reaction to Belhar, see Naude 1997 (Afrikaans). I have taken this matter further in Reformed confessions as hermeneutical problem: A case study of the Belhar confession (Naude 2000, to be published as part of the series on Reformed identity and ecumenicity (editors Michael Welker and Wallace Alston, Eerdmans, 2004). 
Whereas the URCSA is in principle open to a textual reformulation in the light of "a better understanding of the Word of God"40 (church order art 2, my translation), the chances for this are fairly slim. The period to negotiate Belhar's actual content in the process of the DRC family re-union has in my judgement been passed. We shall have to find a way to make Belhar part of the new church as part of the confessional basis brought into the process by the URCSA. Furthermore, the history of Reformed confessions teaches us that a confession's formulation even if later seen as inadequate or even factually wrong - is retained, not so much for what it confesses, but for what it intends to confess. In extreme situations a synod could accept an authoritative explication of such a confession to draw certain hermeneutical boundaries for the understanding of a specific formulation. ${ }^{41}$

\subsection{Specific Text-reception Problems}

Reception problems ${ }^{42}$ regarding the NC-text have been focused on two concepts: homoousios and filioque. This is merely noted, and will not be pursued in this paper. In Belhar, the major debate internal ${ }^{43}$ to the DRC-family has been article 4: "We believe that... in a world full of injustice and enmity He is in a special way the God of the destitute, the poor and the wronged..." Many saw and still see in this formulation a liberation theological reduction of God's revelation and therefore unacceptable as part of a confession. ${ }^{44}$ The formal view of the DRC synod of 1990 is that Belhar is, read by itself, not contradicting the Formulaes of Unity (point 5 of decision) and that article four could have been formulated differently (point 8). The DRC-leadership has indicated in a letter of 8 Nov 1996 that, despite art 4, Belhar cannot simply be dismissed as liberation theological document. ${ }^{45}$ What this paper pursues is whether Belhar as a whole is in theological consonance with the Nicene Creed - and to this end article four will obviously be included in the discussion below.

40. This is quoted from the URCSA's church orders, article 2 (my translation). The full sentence reads: "In the future, changed circumstances as well as a better understanding of God's Word, may lead to the acceptance of new confessions or the alteration of current confessions."

41. For a discussion and concrete examples, see my contribution in Botha and Naude 1998:85-86.

42. I do not specifically address the very important reception-issue related to gender and language. The report of the Churches of Christ in the USA on NC notes: "The language and thought categories of the creed (and the fourth century) were formative for the church. Many believed that they have kept women in powerless places and today impede women from hearing the gospel as saving word" (see Heim 1989:201). A "gendered" reading of both NC and Belhar is an indispensable task which is - as far as I know - still outstanding, although some work by Barabara Zikmund and Susan Thistlethwaite on the trinity and women's experience has been done (for references and discussion, see Stackhouse 1989:168-169).

43. In reading Belhar (Oct - Dec 2002) with an international group of senior students - representing the North and the South, as well as the East and the West - article four created no problems. It was rather the second article on church unity that drew critical dicussion. This illustrates that your reaction is hermeneutically determined by your context!

44. Prof JM Vorster of Potchefstroom University argues inter alia: "The whole revelation of Scripture describes God as God of all people and in a special way the God of the faithful" (1998:478, my translation). See also his article for references in the debate.

45. Apart from the extensive explication of the biblical basis for article 4 by DJ Smit in $A$ moment of truth (Cloete and Smit 1984:53-65), I have attempted to refute the perception that Belhar is a liberation theological document (in the negative sense) in my contribution to Botha and Naude 1998:86-89. 


\subsection{Accompanying Letters}

The issue of reception is made even more interesting if one takes into account that both Nicea and NC as well as Belhar have all been accompanied by a letter ${ }^{46}$ to make its content, intention and authority clear. In the case of Nicea the text has been distributed with a letter to the different synods (Alexandrian letter retained) as well as by a letter written by Constantin to all churches in which he expresses his joy over the restored unity in faith, and declare the Council decisions as law of the state. The Council of 381 sent a letter to emperor Theodosius in which they confirmed the Nicene faith and the restoration of Christian unity, and in which they requested him to confirm the canons and decisions through an edict of the emperor (to which he acceded on 30 July 381).

Where Nicea and NC can and has been read and interpreted without these letters, the opposite is the case with Belhar. Here the accompanying letter is part of the hermeneutical key to the confessional text itself. In four paragraphs the synod clarifies the seriousness of an act of confessions (par 1), explicate their motive (par 2) and the spirit in which the confession is made (par 3), and spells out the aim of reconciliation and unity (par 4). The Belhar letter has been and will be an integral part of the reception process itself and should be taken seriously. (For the sake of the text comparison below, the letter will be taken into account only where deemed necessary).

\section{A Textual and Theological Comparison}

The aim of this section is not to engage in a text (i.e. word by word) comparison, as this is rendered inappropriate by the different genres of $\mathrm{NC}$ and Belhar respectively. But the texts are important, as they obviously act as bearers of theological meaning. The original Greek text of NC and original Afrikaans text of Belhar will serve as points of departure, but, for the sake of a wider readership, discussed via authorised English translations. ${ }^{47}$ As explained at the outset, the focus is on the possible theological consonance between NC and Belhar where NC serves as point of departure. In some cases the text in itself will be the focal point, in others the thematic content as carried by the text, will be important.

\subsection{We believe in (}

In contrast to the Apostolicum (credo in), both $\mathrm{NC}$ and Belhar takes the plural as subject of confession (we believe...). Despite the fact that NC might have partially been built on a baptismal formula, it selects to emphasise the communion of faith which encompasses the individual: As much as the individual's confession is made in communion with the faith of

46. This has almost become a "mark" of creeds and confessions if one takes for example the Belgic Confession and Barmen declaration into account.

47. For NC I follow the text as in Prayers we have in common (agreed litrugical texts prepared by the International Consultation on English Texts, 1975) as used by Confessing the one faith. For Belhar I use the DRMC official translations into English and German, published by the NG Sendingkerk in 1982 (Huguenot: Paarl Drukpers). For the sake of references to Belhar, I will make use of an unofficial numbering of paragraphs for each of the five articles: Articles 1 and 5 has no subdivisions (unless one reads the doxology of art 5 as a separate paragraph which I will, for reference purposes, not do). The three middle articles are divided into the paragraphs as printed in the Afrikaans and subsequent translations. The only difficulty is in article 2 which starts with a general statement (We believe in one...church.) and is then followed by six paragraphs We believe that ... In this case 2.1-2.6 refer to these explicating paragraphs. Article 3 thus has four paragraphs (3.1-3.4) and article 4 has three (4.1-4.3). The rejections will be linked to the relevant article and cited in order of appearance, e.g. article 2 , rejection 2 or, where only one rejection clause appears like in articles 3 and 4, it will be called rejection, article 3 or rejection, article 4 . 
the whole church, so much the communal confession articulates the faith of the individual. And despite the precedence of the Apostolicum in the Reformed tradition, one would have expected the plural form in Belhar, because the subject of a confession over against a heresy is the church who also acts as first recipient of such a confession (see Barth 1948:713, 725).

In NC pisteuomen eis is repeated four times with reference to the Trinity (once for each Person) and significantly includes the church as object of confession. In Belhar "we believe in" occurs two times, but the first includes the Triune God as a unity without separate articles for each of the three Persons, and the second refers to the church. With regard to the latter, Belhar's Afrikaans text follows the Apostolicum where "glo in" is reserved for God and "glo aan" is used for the article on the church. ${ }^{48}$ As a positive explication of the gospel and true to its nature as Bekenntnisschrift, Belhar includes quite a number of "we believe that"-statements ${ }^{49}$ that serve as mirror image of the "we reject"-clauses in the three middle articles.

Already in the very opening lines we see a double convergence between NC and B: They both take the confessing church as subject, and both take the Triune God and the church as "objects" of confession. The question now arises whether this points to a deeper thematic consonance. For this we turn first to the confession of the Trinity:

\subsection{Trinitarian Theology as Basis for Ecclesiology}

We have already seen above that Nicea and NC were formulated in the context of the development of the early church's understanding of the Trinity. One can therefore expect that the Three Persons would be confessed both in their own Personhood, and in their interrelation to one another.

The first that strikes one is the strong emphasis on unity in the Nicene Creed: We

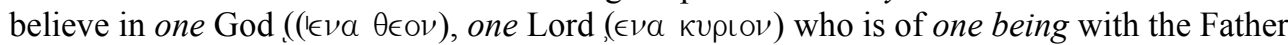

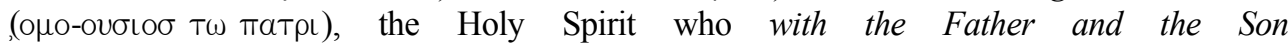
$\left.\left(\sigma \cup \nu \operatorname{mat\rho \iota } \kappa a \iota^{\imath} v(\omega)\right)\right)$ is worshipped and glorified; and we believe in one church ( $\mu \iota \alpha \nu \in \kappa \kappa \lambda \eta \sigma \iota \alpha \nu)$. The focal point of the unity is the Trinity as one God (against forms of tri-teism) where Father, Son and Spirit are equally divine (against forms of subordianism) and from whose grace the church as one church is established (against ecclesial division ${ }^{50}$ due to doctrinal differences).

It is instructive to note that Belhar takes the outcome of the struggle for the church's trinitarian faith as expressed in NC as its very starting point: We believe in the triune God, Father, Son and Holy Spirit. In this manner Belhar establishes itself on the ecumenical faith of the church through the ages. The unity of God - so eloquently expressed in NC - is taken up in the very last sentence of Belhar: To the one and only God, Father, Son and Holy Spirit, be the honour and the glory for ever and ever. This reminds strongly of the doxological phrase in the Nicene article on the Holy Spirit Who with the Father and the

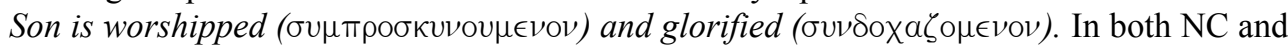

48. This distinction between credere in and credere is not possible in English.

49. "We believe that..." is used six times in art 2 (unity), four times in art 3 (reconciliation), three times in art 4 (justice) and once in art 5 (obedience).

50. It should again be noted that both Nicea and NC were called by the emperor to heal specific doctrinal rifts in the church, although both Councils obviously also dealt with other issues like church governance, appointments of bishops, and many other agenda points. 
Belhar the Trinitarian faith is doxologically and antithetically ${ }^{51}$ expressed and, if we read the Belhar phrase in conjunction with the very first line of the confession, it emerges that trinitarianism in fact begins (underlies) and ends (takes forward) the confession itself.

But where the trinitarian faith is - due to the nature of the heresies - itself expounded and defended in NC, Belhar takes this faith as assumption to shift the focus from the unity of God to the unity of the church, because the heretical situation against which Belhar witnesses, is an ecclesial one of separated churches for people of different racial descent. In Belhar there is therefore a "contraction" of the Nicene Creed so that belief in the triune God is immediately linked to the church in a double movement, each of which confirms $\mathrm{NC}$ in an interesting way.

In art 1 We believe in the triune God, Father, Son and Holy Spirit is in the same breath followed by who gathers, protects and cares for his Church by his Word and his Spirit, as He has done since the beginning of the world and will do to the end. This is in line with the structure of both $\mathrm{NC}$ and the Apostolicum. But where $\mathrm{NC}$ had to give extensive detailed formulations on the pre-existence of the Son and the Spirit, ${ }^{52}$ Belhar links the triune God's "pre-existence" (from the beginning of the world) and "post-existence" (and will do to the end) not so much to God self, as to the establishment and protection of the church. To a certain extent $\mathrm{NC}$ focuses on the immanent trinity ${ }^{53}$ whereas Belhar focuses on the economic Trinity as manifested in the history of the church.

This is immediately followed by the second movement, i.e. in the "heading" of art 2 which deals in its entirety with the unity of the church: We believe in one, holy, universal Christian Church, the communion of saints called from the entire human family. In a very delicate way Belhar here draws on both $\mathrm{NC}$ and the Apostolicum. For the unity of the church - which is the core focus of article 2 - Belhar takes over the NC-adjective of one church (which is absent from the Apostolicum). This is followed by the Apostolicumformula (the apostolic from $\mathrm{NC}$ is therefore not included), with a non-creedal addition derived from the Heidelberger Catechism namely, that the community of saints is called from the entire human family.

In the light of the heresy against which Belhar confessed, it thus derives the unity of the church in article 2 from NC, and elaborates this unity in the four ensuing paragraphs (unity as gift and obligation; unity as visible; unity as manifested in a variety of ways; unity established in freedom). The reference to the church as a communion of saints enables Belhar to implicitly assert a contradiction to a view of community where differentiation is seen as ground for separation instead of opportunities for mutual service and enrichment in the one visible people of God. That the church is called from the entire human family enables Belhar to implicitly already assert the unity of the church against the heresy that descent or any other human and social factor should be a consideration in determining membership of the Church (article 2, rejection 3).

51. There is little doubt that this doxological formulation in the Nicene Creed is crucial to emphasise the divinity of the Spirit. In Belhar the doxology starts with Jesus is Lord, and is imbedded in article 5 where obedience to Jesus Christ is set against obedience to authorities and human laws. See discussion of Lordship of Christ below.

52. This emphasis is evident in the description of the Son as "eternally begotten"

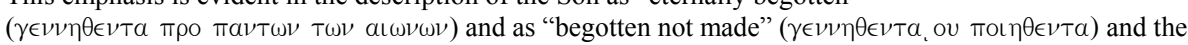

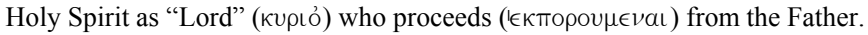

53. This distinction is obviously a construction we put on NC today. Due to the heresies it had to confront, the intra-trinitarian confession was necessary, but - as will be seen below - NC is in its Christology as historically related as any "economic" theology could be. 
The theological structure of NC (and the Apostolicum) is clearly maintained, but in line with the context and heresy of Belhar, the Trinitarian base of faith is translated into more elaborate ecclesiological terms so that the unity of the triune God becomes motivation for and is reflected in the unity of the community of saints. In this way articles one and two of Belhar, as well as the closing section of article five, are in full consonance with the apostolic faith expressed in the Nicene Creed.

\subsection{Christology}

In the light of the Arian heresy, NC had to give detailed attention to the divinity of the Son. This is accomplished in eight expressions from one Lord to Through him all things were made. After the Godhead of Christ is firmly established, NC proceeds to confess the incarnated humanity of the Son starting with He came down from heaven and ending in $\mathrm{He}$ ascended into heaven (in a series of expressions later closely followed by the Apostolicum). This twofold christological structure is present in Belhar, but interpreted in a particular way commensurate with the aim of the confession.

\section{The Divinity of Christ: His Lordship}

The oldest confession of Christ's divine status, already present in the New Testament (e.g. Rom 1:3, 1 Cor 8:6 and 1 Cor 12:3), is that He is Lord. $\mathrm{NC}$ is clear and simple: We believe in one Lord, Jesus Christ. The one Lord is in line with NC's emphasis on the unity of God; the one Lord expresses the ultimate rulership and authority of Christ whose kingdom will have no end. Where this confession was a case of life and death in early Christianity (a challenge to the emperor), the Nicene Creed was formulated under political conditions where this would be accepted by the Roman authorities, and therefore expressed in relative freedom.

The Lordship of Christ emerges in Belhar under conditions reminiscent of early Christianity. After the confession of unity, reconciliation and justice, Article 5 expresses a challenge and a conviction:

We believe that, in obedience to Jesus Christ, its only Head, the Church is called to confess and to do all these things, even though authorities and human laws might forbid them and punishment and suffering be the consequence. Then follows: Jesus is Lord, after which the Trinitarian doxology discussed above is inserted.

I have in a previous paper (Naude 2002b) shown that Belhar's confession of Christ's Lordship exhibits the same bi-focal vision of antecedent church witnesses. Christ is firstly Lord of the church, but also Lord of history and society. This is beautifully formulated in article five where the Headship of the Church and Lordship over human authorities are juxtaposed in calling the church to confess and do all these things... Where the church follows its only Head in obedience to his rule and is resisted by authorities and human laws, the higher commitment to the Lord will prevail.

\section{The Humanity of Christ: His Incarnation}

The connection between NC and Belhar concerning the humanity of Christ is evident from three crucial phrases that puts the whole of Christ's earthly work in a strong pro nobis-

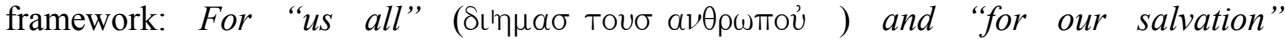

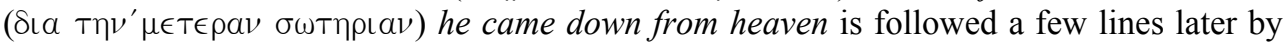




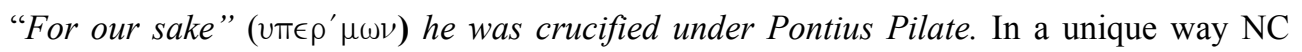
makes clear that Christ's work was directed at humans and their salvation and should therefore be interpreted in such a way that the reality of this salvation is honoured. Although NC does not provide us with a specific salvation-historical theology, it would be fair to suggest that this salvation is epitomised in incarnation-as-reconciliation. Christ was crucified for our sake in the sense that he took upon Him our sins and was crucified in our place. And this He did for us all, reconciling humankind to God (Col 1:15-20), the first fruit of which is the church as those reconciled to God and one another because they accept Christ's work as for our sake.

In this way the transition from unity to reconciliation - so central to articles 2 and 3 in Belhar - is made within the framework of the Nicene Creed itself. In article 2 Belhar confesses that Christ's work of reconciliation is made manifest in the Church as the community of believers who have been reconciled with God and with one another. Christ's work of reconciliation is a theological summary of the incarnated Christ, and the pro nobischaracter is reflected in the church as community of reconciled people in the same way that NC link the church to the work of the Trinity (obviously including the Son). Belhar therefore rests fully on the basis of the incarnate Christ as confessed in NC, and, under threat of a serious defilement of the gospel, expands NC to spell out what the concrete implications of Christ's work for our salvation and for our sake are.

Belhar's concern is therefore with the visibility of our salvation and therefore substantially confesses the manifest unity of the church in art 2 and reconciliation amongst people in the world as fruit of this beneficial work (Belhar 3.3) in the whole of article 3. Needless to say: making salvation concrete is for Belhar an ecclesiological matter because We believe that God has entrusted to his Church the message of reconciliation in and through Jesus Christ (art 3 first line). In this way both the Christological and ecclesiological implications of NC are made explicit in the context from which Belhar spoke.

\subsection{Pneumatology: The Spirit as Giver of Life and Prophecy}

We know from text-comparisons that the most additions of NC (381) to the original Niceatext (325) relate to the article on the Spirit (see discussion above). For our purposes, two of

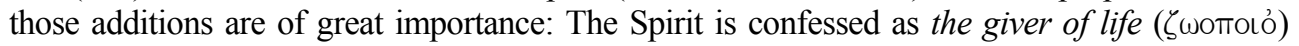

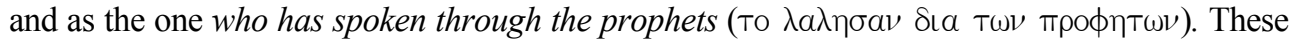
must be read against the background of the denial of the godhead of the Spirit:

The first formulation relates to John 6:63 (the Spirit gives life) Rom 8:2 (the law of the Spirit of life) and 2 Cor 3:6 (the letter brings death, but the Spirit brings life) and emphasises the life-giving work of the Spirit where life is understood in both physical (see context of bread in John 6) and spiritual terms. The second formulation relates to 2 Pet 1:21 and brings a unity between the Spirit and the Word of God spoken through the prophets. The intention of NC is clear: Only God gives life and it is God that speaks through the prophets; therefore the Spirit is equally part of the godhead and should be worshipped and glorified with the Father and the Son.

In Belhar, the work of the Spirit as "life-giver" and "Word-giver" is intimately related to one another in a Trinitarian context and externally related to four realities: The establishment of the church (art 1); the unity in the church (art 2); reconciliation in society and the world (art 3), and ultimately justice for the destitute, the poor and the wronged (art 4):

Article 1: We believe in the triune God, Father, Son and Holy Spirit, who gathers, protects and cares for his Church by his Word and his Spirit... The manner in which the 
triune God establishes and leads the church through history is via the Word-giving and life-giving Spirit.

In article 2 it is confessed that through the working of God's Spirit it (the unity established by Christ's reconciliation) is a binding force; that believers are filled with one Spirit, and that the variety of spiritual gifts... as well as the various languages and cultures, are by virtue of the reconciliation in Christ, opportunities for mutual service...

In article 3 we find a much more direct link to the Nicene text: After confessing that God has entrusted the message of reconciliation to the church, Belhar follows in 3.2 with a twofold repetition of the Nicene phrase referred to above:

We believe that God by his life-giving Word and Spirit has conquered the powers of sin and death, and therefore also of irreconciliation and hatred, bitterness and enmity; that God by his life-giving Word and Spirit will enable His people to live in a new obedience which can open new possibilities of life for society and the world. This powerful formulation gives a distinct cosmic and social interpretation of the Word-giving and Life-giving Spirit because God (negatively) conquers social irreconciliation and (positively) opens new possibilities of life for society and the world.

This enables Belhar to make the third and last transition from unity and reconciliation to justice in the article 4 :

We believe that God has revealed himself as the One who wishes to bring about justice and peace among men; that in a world full of injustice and enmity He is in a special way the God of the destitute, the poor and the wronged and that He calls his Church to follow Him in this...

Belhar commences its fourth article with an important revelatory theo-logical statement about the manner of God's revelation in the world. God is known to us via Jesus Christ and the Spirit. And NC already confessed that the incarnation of Christ occurred by the power of the Spirit. What Belhar does, is to link Jesus' incarnation via the Spirit (i.e. his revelation of God) not only to his birth from the virgin Mary, his crucifixion, death, burial and resurrection, but to the manner of his ministry in the world. The crucial "markers" of Christ's humiliation and humanity - so well known from both NC and the Apostolicum - is "filled in" with the "markers" of his self-donating ministry in the world as clearly attested to in the gospels: $:^{54}$

After news of the incarnation, the very same Mary, filled with the Spirit, sings a song of praise to God who will be revealed as the One who cares for the hungry and lift up the downtrodden (Luke 1:46-55). The angels bring praise to God as One who through his Son brings peace on earth (Luke 2:14). And the young Jesus reads from the prophet Isaiah and claims that the Spirit is upon Him to proclaim the good news to the poor (Word-giver and life-giver!), freedom to those in prison, and restoration of sight for the blind (Luke 4:16-19). The sermon on the mount commences with the well-known beatitude: Blessed are you, the poor, for to you the kingdom of God belongs (Luke 6:19), whereas the parable of the rich man and Lazarus inverts the order of material and social status in favour of the poor (Luke 16:19-31).

On this basis Belhar can formulate in revelatory language: We believe that God has revealed himself as the One who wishes to bring about justice and true peace... This is the same God who in Christ for us all and for our salvation came down from heaven (NC) to

54. Other than $\mathrm{NC}$, we find lists of Scriptural references throughout Belhar. I here follow the Lukan line of exploring Jesus' ministry as suggested in Belhar article 4. 
establish reconciliation, peace and justice on earth (Belhar). Belhar gives a further concrete explication of the Incarnated One, and in a situation of structural and racial injustice, and of human oppression, confesses that Christ's ministry for us all became a ministry focused on the destitute, the poor and the wronged, because in God there is no injustice. This is the apostolic faith of the ecumenical church today. ${ }^{55}$

\subsection{We acknowledge ${ }^{56}$ one Baptism for the Forgiveness of Sins}

If one remembers that $\mathrm{NC}$ arose from the baptismal faith of the early church, the link

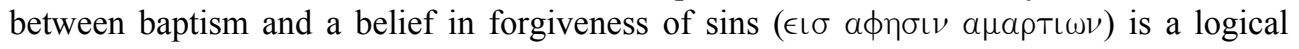
one: baptism was the sign of forgiveness of sins through the blood of Christ and serves as incorporation into the body of Christ.

In Belhar this meaning of baptism and sin is assumed and retained, but interpreted in the direction of the confession's own intention: In the article on the unity of the church the reference to one baptism from Eph 4 (article 2.4) does not so much emphasise introduction into the church as a call to focus on the fact that those believers, now divided by human measures, are baptised with the one baptism and together fight against all which may threaten or hinder this unity. Baptism is entrance into a new communion where human divisions of culture, class, and sex are transcended, because we are all children of God (Gal 3:26-29). We are in Christ one church and we already share one baptism, therefore we cannot give up the precious visible unity of the people of God. In other words, Belhar, arising from a painfully divided church, is concerned about the "entrance" into visible unity based on the already achieved "entrance" into the church, exactly because we confess one baptism.

$\mathrm{NC}$ focuses on the forgiveness of sins (plural form) which leaves the creed open for interpretation of both individual and communal sins (the plural subject), as well as on the ongoing forgiveness through a reappropriation of baptism. This social or structural dimension is overtly present in Belhar: Article 2.3 states that separation, enmity and hatred between people and groups is sin which Christ has already conquered, and article 3.2 refers to the belief that God has conquered the powers of sin and death, and therefore also of irreconciliation and hatred, bitterness and enmity. These social-structural descriptions of sin (separation, hatred between people, etc) are in both instances embedded in the confession that sin - in whatever form - has already been conquered by God in Christ (art 2) and the Spirit (art 3). And the Scriptures are clear: from this power we have been freed through baptism as a sign that we have been buried with Christ, but also resurrected with Him who conquered all authorities and powers (Col 2:6-15) - including the law-enforced irreconciliation amongst peoples and groups in a land that professes to be Christian (Belhar art 3.3).

\subsection{We Expect the Resurrection of the Dead and the Life of the Age to Come}

The Nicene Creed ends with an encompassing eschatological vision that includes both the personal hope of resurrection and the cosmic hope of a new creation. Against Gnostic or Manichaean ideas of a purely "spiritual" future, the creed - on the basis of Christ's

55. See confirmation of this hermeneutical perspective in Confessing the one faith 1991, paragraphs 120, 153-161, 277. For people who suffer, "God's solidarity enables them to struggle against suffering and death in all its manifestations. In the particular case of human oppression, the victim is assured that God is never on the side of the oppressor, the bringer of death, but will, in his justice, protect the rights and lives of the victims" (par 157 , last sentence my emphasis).

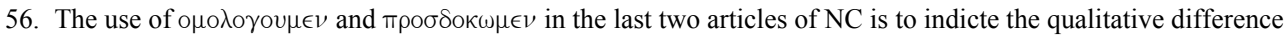
with $\pi\llcorner\sigma \tau \in \cup O \mu \in v$ which is reserved for the Trinity and (in NC) for the church. 
resurrection - attests to the future of believers as an all inclusive personal future in God's presence. And from God's purpose to set all things in heaven and on earth under Christ (Eph 1:10), springs the hope for all of creation to be transformed as God's kingdom reaches its fulfilment in a new heaven and a new earth (Isa 65:17; Rev 21). This hope, testifies the oikumene, finds expression in the church as a communion of hope $\mathrm{e}^{57}$ as "a sign of God's future for the renewal of humanity" (Confessing the one faith 1991, par 272).

Belhar, so deeply aware of the contingencies of history, is an equally strong eschatological confession. As already shown above, article 1 confesses God's work in the Church since the beginning of the world and unto its end. The doxology in article 5 with which Belhar ends professes honour and glory forever and ever, opening history in the forward movement of the church, taken up in praise to God. Apart from these two eschatological concerns related to history in its relativity, Belhar - like the explication of Nicea ${ }^{58}-$ also takes present history seriously. This is best expressed in a reference with a clear tone of a realised and realisable eschatology:

We believe that the Church is witness both by word and by deed to the new heaven and the new earth in which righteousness dwell (3.1). Where the church lives reconciliation and unity within itself, and establishes such reconciliation with words and deed outside of itself as salt of the earth, the new heaven and new earth already become visible. In the language of article four: If the Church follows Jesus in serving the destitute, the poor and the wronged; and stands by people in any form of suffering and need; and as the possession of God stands where God stands, namely against injustice and with the wronged, the righteousness of the new earth is already realised exactly as sign of the coming age confessed in the Nicene creed.

\section{Conclusion}

There are obviously many differences between NC and Belhar. To some of these we have referred above. But I am convinced that Belhar confesses the same apostolic faith as the one ecumenical church, universal in time and space. Reading from the 21 st century, this is a vindication of the remarkable and during significance of a creed stemming from the fourth century after Christ. But it is equally a vindication of a confession from the late twentieth century from a place where few saw any reason for hope and expectation.

Nicea and Belhar therefore strengthen our faith as they testify to the ongoing revelation of our one God who is to be worshipped and glorified (NC) forever and ever (Belhar).

57. See the discussion of The church: A communion of hope in section V of $A$ common account of hope, F\&O Paper 92, 1978.

58. The Confessing the one faith interpretation reads: "We are impelled by our hope to work for a more humane and just world. Our pursuit of justice and peace within history cannot bring about the kingdom, but our work is done in the trust that nothing of what we have done in expectation of the Holy City is in vain..." (par 275, emphasis original). 


\section{BIBLIOGRAPHY}

Arens, Edmund 1989. Bezeugen und Bekennen. Elementäre Handlung des Glaubens. Dusseldorf: Patmos.

Barth, Karl 1948. Kirchliche Dogmatik I/2. Zürich: Evangelische Verlag.

Barth, Karl 1951. Kirchlichen Dogmatik III/4. Zurich: Evangelische Verlag.

Barth, Karl 1962. Theology and the Church. Shorter Writings 1920-1928. New York: Harper\& Row.

Bate, HN (ed.) 1928. Faith and Order. Proceedings of the World Conference in Lausanne, August 3-21, 1927. New York: Doubleday.

Botha, Johan and Naude, Piet 1998. Op pad met Belhar. Goeie nuus vir gister, vandag en more. Pretoria: Van Schaik.

Botman, Russel 2000. Is Blood Thicker than Justice? The Legacy of Abraham Kuyper for Southern Africa. In Lugo, Luis E (ed.): Religion, Pluralism and Public Life. Abraham Kuyper's Legacy for the Twenty-first Century. Grand Rapids: Eerdmans, 342-361.

Cloete, GD and Smit, DJ (eds.) 1984. A Moment of Truth. Grand Rapids: Eerdmans.

De Gruchy, John W 1979. The Church Struggle in South Africa. Cape Town: David Philip

Hauschild, Wolf-Dieter 1994. Nicäno-Konstantinopolitansiches Glaubensbekenntnis. TRE 24, 444-456.

Heim, Mark S (ed.). 1989. Faith to Creed. Ecumenical Perspectives on the Affirmation of the Apostolic Faith in the Fourth Century. Grand Rapids: Eerdmans.

Houtepen, Anton 1991. Common Confession. In Dictionary of the Ecumenical Movement, 195-197.

Jonker, WD 1977. Christus die Middelaar. Pretoria: NGK-Uitgewers.

Kinghorn, Johann (ed.) 1986. Die NG Kerk en apartheid. Johannesburg: Macmillan.

Kelly, JDN 1972. Eary Christian Creeds (third edition). London: Longman.

Limouris, Gennadios 1991a. Historical Background of the Apostolic Faith Today. In Confessing the One Faith, 105-111.

Limouris, Gennadios 1991b. Nicene Creed. In Dictionary of the Ecumenical Movement, $727-728$.

Nederduits Gereformeerde Sendingkerk 1982. Konsepbelydenis van die NG Sendingkerk in Suid-Afrika. Huegenot: Paarl Drukpers.

Naude, Piet 1997. Die Belharstryd in ekumeniese perspektief. NGTT xxxviii/3:226-243.

Naude, Piet 2000. Reformed Confessions as Hermeneutical Problem: A Case Study of the Belhar Confession. Unpublished paper delivered at the Centre for Theological Inquiry (Princeton) conference on Reformed Identity and Ecumencity, University of Heidelberg, Germany, March 2000.

Naude, Piet 2001. The Dutch Reformed Church's Role in the Context of Transition in South Africa. Main Streams of Academic Research. Scriptura 76, 87-106.

Naude, Piet 2002. Confessing Nicea today? Critical Questions from a South African Perspective. Scriptura 79, 47-54.

Naude, Piet 2002a. From Pluralism to Ideology. The Roots of an Apartheid Theology in Abraham Kuyper, Gustav Warneck and Pietism. Unpublished seminar paper: University of Heidelberg, Germany. 
Naude, Piet 2002b. The Theological Conherence between Belhar and some Antecedent Church Witnesses in the Period 1948-1982. Unpublished seminar paper: University of Heidelberg, Germany, 2003.

Naude, Piet and Smit, Dirk 2000. 'Reception' - Ecumenical Crisis or Opportunity for South African Churches? Scriptura 73: 175-188.

Oberdorfer, Bernd 2000. Filioque. Geschichte und Theologie eines ökumenischen Problems. Göttingen: Vandenhoeck \& Ruprecht.

Perrone, Lorenzo 1993. Von Nicea (325) nach Chalcedon (451). In Alberigo, Guiseppe: Geschichte der Konzilien: Vom Niceaum bis zum Vaticanum II (Dusseldorf: Patmos), 22-83.

Ritter, Adolf Martin 1978. Arianismus. TRE 3, 693-719.

Ritter, Adolf Martin 1999. Dogma und Lehre in der alten Kirche. In Andresen, Carl und Ritter, Adolf Martin: Handbuch der Dogmen- und Theologiegeschichte, vol 1. (Göttingen: Vandenhoeck \& Ruprecht), 99-221

Sieben, Hermann Josef 1979. Die Konzilidee der alten Kirche. Paderborn: Ferdinand Schöningh.

Smit, DJ 1984. In a special way the God of the destitute, the poor, and the wronged. In Cloete and Smit (eds.), 53-65.

Smit, DJ 1998. Das Bekenntnis von Belhar: Entstehung, Rezeption, Relevanz. In J Niemöller: Das Bekenntnis von Belhar und seine Bedeutung fur die reformierten Kirchen in Deutschland. (Detmold: Reformierte Kirche), 17-33.

Stackhouse, Max L 1989. The Trinity as Public Theology: Its Truth and Justice for FreeChurch, Non-credal Communities. In Heim, Mark S: Faith to creed, 162-197.

Vandervelde, George 1988. The Meaning of Apostolic Faith in World Council of Church's documents. In Horgan, Thadeleus (ed.): Apostolic Faith in America. (Grand Rapids: Eerdmans), 20-25.

Verenigde Protestantse Kerk in Belgie 2001. De belijdenis van Belhar en haar betekenis voor ons. Brussel: VPKB.

Villa-Vicencio, Charles 1986. Between Christ and Caeser. Classic and Contemporary Texts on Church and State. Cape Town: David Philip.

World Council of Churches 1971. Louvain. Faith and Order Paper 59. Geneva: WCC.

World Council of Churches 1978. A Common Account of Hope. Faith and Order Paper 92. Geneva: WCC.

World Council of Churches 1990. Baptism, Eucharist and Ministry 1982-1990. Faith \& Order Paper 149, Geneva: WCC.

World Council of Churches 1991. Confessing the One Faith (new revised version). Faith and Order Paper 153. Geneva: WCC. 